\title{
Retained Water in the Commune of Gogounou in Benin: Inventory, Characterization and Management Mode
}

\author{
Roger Masso Sourogou, Fabien. C. Hountondji
}

\begin{abstract}
The present work was carried out with the aim of knowing the characteristics and the management made of the agropastoral dams of the commune of Gogounou which are of a great utility for the local populations. To do this, twenty (20) dams were chosen according to the strategic interest that they present for the population, that is to say a polling rate of $87 \%$ on all the dams of the municipality. An inventory of the dams was made according to quantitative and qualitative indicators. The results showed the existence of (04) groups of dams according to the technical characteristics and some qualitative variables. The parameters that lead to the degradation of these dams are often related to the age and type of dam and the place of installation. Groups ( 2 and 4 ) are agropastoral dams $(100 \%)$ and more than half of the dams are on flood sites. Results have also shown that there are management committees around all the dams in the commune of Gogounou, but which are mostly non-functional at almost $\mathbf{7 5 \%}$. Also, it has been found that the breeders are mostly transhumant and sedentary who use $(\mathbf{1 0 0 \% )}$ dams for watering animals. This cohabitation between farmers and pastoralists does not occur without major conflicts, in particular, that of land whose settlement is generally peaceful. In short, the management of the dams in the commune of Gogounou is a real challenge to be met for a better development, both economically and socially to guarantee the prosperity of the actors and prepare them to adapt to the vagaries of the climate future.
\end{abstract}

Keywords -agro-pastoral dams, categorization, Gogounou, management.

\section{INTRODUCTION}

The agro-pastoral sectors play a crucial role in the process of economic and social development in Benin. But it is clear that currently, the sector faces a number of constraints which limit its development and risk compromising its sustainability. This results in unfortunate consequences in terms of agricultural water needs and those of livestock which are no longer satisfied. The dams allow today to ensure a certain annual availability of water in order to secure the practice of economic, agro-pastoral and socio-cultural activities.

It is for the sake of better understanding the management of these water sources that this study was undertaken in the district of Gogounou. To do this, twenty (20) dams were chosen according to the interest they present for the populations, i.e. a survey rate of $87 \%$ on all of the dams in the municipality. The inventory of dams showed the existence of (04) groups of dams according to the technical and qualitative characteristics, in particular the dimensions, the storage capacity, and the type of dam and the place of installation. These 


\section{sciendo}

116 Ovidius University Annals Series: Civil Engineering, Year 22, 2020

characteristics are related to the degradation parameters of these dams. Although there are management committees around most of the dams, they are almost $75 \%$ non-functional. The cohabitation between farmers and breeders creates major conflicts, particularly related to land, the mode of settlement of which is generally peaceful. This information is necessary for efficient and sustainable management of dams in order to meet the development challenge, both economically and socially of the actors involved and prepare them to adapt to future vagaries of the climate.

For others, with downstream irrigation systems for still others. However, since the construction of these reservoirs and their uses, ecosystem management has revealed many problems. According to the local administration of Gogounou, the lack of active participation of water users and the non-functioning of the various management committees partly explain the problem. But for other actors, the non-concerted management of the authorities is a more serious reason. It is to find an approach to solutions to the many concerns of equalization between the reservoirs and their management that this study was initiated and aims to categorize and revise the method of managing reservoirs in the municipality from Gogounou, for redesign these works In specific ways, it is a matter of: (I) Inventing the water reservoirs and their functions in the commune of Gogounou, (II) evaluating the state of management of the reservoirs in the commune of Gogounou, and (III) propose perspectives for the development and management of the ecosystem of the reservoirs studied.

This environment constitutes the field of study of our work, which requires the constitution of databases and the choice of suitable methods. Poor design, climatic factors, lack of monitoring and maintenance and above all poor water management contribute, for the most part, to the hasty degradation of these structures. So to remedy such situations, it will be necessary to conduct a study on the reservoirs of water in this municipality in their entirety, their characteristics and management method, in order to propose prospects for efficient and sustainable development and management of the ecosystem of the reservoirs studied.

\section{METHODOLOGICAL FRAME WORK OF THE STUDY}

\subsection{Presentation of the study environment}

Located more than $615 \mathrm{~km}$ from Cotonou in the north of the Republic of Benin, the Commune of Gogounou is the gateway to the department of Alibori from the south. It is crossed by the RNIE 2 Benin-Niger for $45 \mathrm{~km}$. The Municipality of Gogounou is located between $10^{\circ} 33$ ' and $10^{\circ} 57^{\prime}$ 'North latitude and $2^{\circ} 15^{\prime}$ 'and $3^{\circ} 15^{\prime}$ East longitude (Figure 1). With a population of 117,523 inhabitants including 59,505 women, it covers an area of $4,910 \mathrm{~km}^{2}$; which represents $18.66 \%$ of the entire Alibori department $\left(26,303 \mathrm{~km}^{2}\right)$ and $4.36 \%$ of the entire national territory [11].

\subsection{Sampling techniques}

The criterion that leads to the choice of localities surveyed is "the presence of a dam". To this end, 20 dams have been retained out of the 23 in the commune of Gogounou. This represents a survey rate of $87 \%$. The other three were abandoned for several reasons, including their total drying up. The table below provides information on the distribution of dams according to the districts. 


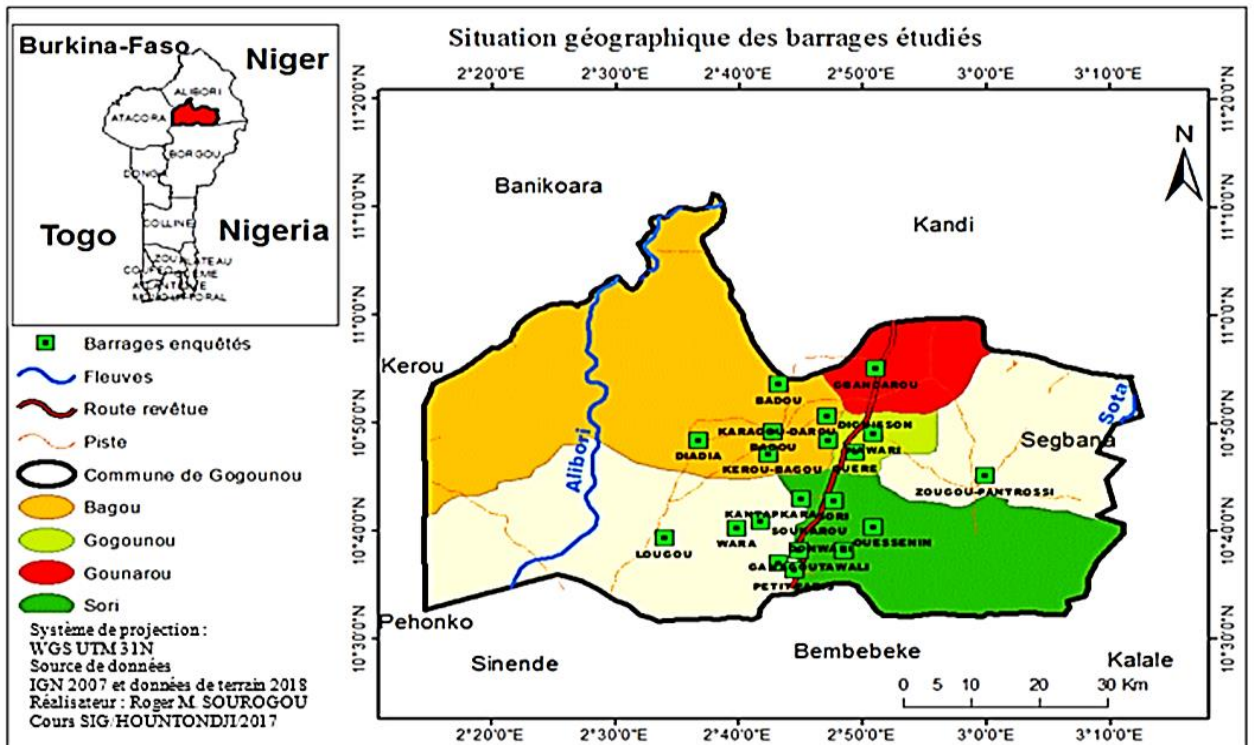

Fig. 1 Geographic location of the study area and the sampled dams

\subsection{Data collection tools and techniques}

\subsubsection{Data collection tools}

For the purposes of the survey, questionnaires and interview guides were developed according to the different categories of actors involved in the management or use of the dam management committee, farmers, breeders and fishermen).

In addition, a GPS (Garmin 62S) was used for the geo-referencing of the dams studied. Regarding the means of movement, three motorcycles were used for the supervision of the investigative agents.

\subsubsection{Data collection techniques}

Data collection was done in two phases. The first phase was devoted to documentary research in the institutions involved in the construction of dams in the town of Gogounou (the town hall, CARITAS BIBD etc.) and other organizations likely to provide information.

For the analysis of the conflicts related to the management of the dams, exchanges took place with the different users, especially with the members of the offices of the dam management committee. They are, among others, farmers, breeders, members of the management committee or resource persons.

For the analysis of the conflicts related to the management of the dams, exchanges took place with the different users, especially with the members of the offices of the dam management committee. They are, among others, farmers, breeders, members of the management committee or resource persons. To assess the impact of the quantity of water withdrawn by the various users (breeders, farmers, population, SMEs and others) at the dam level, the survey agents noted the quantities of water withdrawn by the users, each day of 7 a.m. to 6 p.m., this for seven (07) days. The work of the author [2] allowed us to estimate the amount of water taken by the farm, based on the number of animals that came to drink at the dam during this period (an average of $30 \mathrm{~L} / \mathrm{j}$ for large ruminants and $5 \mathrm{~L} / \mathrm{j}$ for small ruminants). 


\section{sciendo}

118 Ovidius University Annals Series: Civil Engineering, Year 22, 2020

For farmers, the general public, SMEs and other users, the amount of water has been estimated based on the number of cans, basins, tanks, watering cans, barrels used to collect water during this period. This amount has been converted to cubic meters. Data processing methods from field observations and technical data from the dams, bar histograms, circular diagrams and statistical tables have been established to assess the state of dams in the municipality and establish the rate of degradation of the dams. Excel 2013 software was used to enter and encode the data collected in a database designed from the interview guide and survey questionnaires. The Arc GIS 10.1 software was used for the production of the maps and the "Cactus2000: Precipitation" site [7], for the conversion in the ETP calculations.farmers, the general public, SMEs and other uses, the quantity

Statistical analyzes were carried out using R software version 3.4.1, 2017 through factorial correspondence analysis (AFC). The analysis and interpretation of the results were done through the commentary on the graphs. To assess the availability of water at the dams, the total amount of water withdrawn (QTotal) was calculated over seven (7) days. It is expressed by the following formula:

$$
\text { QTotal = QAgri + QElvg + Qpop + ETP }
$$

with: QAgri, quantity of water taken by farmers to irrigate the estimated areas, in $\mathrm{m}^{3}$, QElvg, quantity of swater taken by breeders, in $\mathrm{m}^{3}$;

Qpop, quantity of water withdrawn by the population and SMEs, in $\mathrm{m}^{3}$ ETP, potential evapo transpiration in $\mathrm{m}^{3}$.

The potential evapotranspiration (ETP Penman) of the Benin basin of the Niger river calculated by ASECNA for the period from 1975 to 2010 is $1710 \mathrm{~mm}$. It is maximum in March (179 mm) and minimum in August $(115 \mathrm{~mm})$ [14]. For the present research work we have considered the maximum FTE179mm. This gives $179,000 \mathrm{~m}^{3} / \mathrm{km}^{2}$ or $1,790 \mathrm{~m}^{3} / \mathrm{ha}$, so the ETP of $447.5 \mathrm{~m}^{3} /$ ha for the week. Thus the calculated evapotranspiration is a function of the area of each basin of the dam considered. To the water available watershed, the climate balance was used. It is expressed by the following formula: $\mathrm{Bc}=\mathrm{P}-\mathrm{ETP}$, with: $\mathrm{Bc}$, climate balance in $\mathrm{mm}, \mathrm{P}$ : total annual rainfall in $\mathrm{mm}$, ETP, actual evapotranspiration in mm According to Hufty, (1976):

- If P - ETP> 0, then the balance sheet is in surplus;

- If $P$ - ETP $<0$, then the balance sheet is in deficit;

- If $\mathrm{P}$ - ETP $=0$, then the balance is balanced.

The Statistical tools for descriptive and classification analyzes were used for multivariate analysis in PCA (Excel, R 3.5.3).

\section{RESULTS AND SIGNIFICANCES}

\subsection{Technical characteristics of dams}

Analysis of Table 1 reveals that dams are on average eighteen (18) years old. The oldest dam is twenty-four (24) years old and the oldest is twelve (12) years old. The results also reveal that the average length of the dike is $182.3 \pm 78.2 \mathrm{~m}$; the average length of the spillway is $24.6 \pm 10.2 \mathrm{~m}$; the average depth of the bowl is $4.4 \pm 1.5 \mathrm{~m}$; the average maximum capacity of the dams is $55,220 \pm 18,961 \mathrm{~m}^{3}$; the nearest mean field distance to the dam is $60.1 \pm 88.7$ $\mathrm{m}$; the average distance from the village closest to the dams is $960 \pm 839 \mathrm{~m}$. 


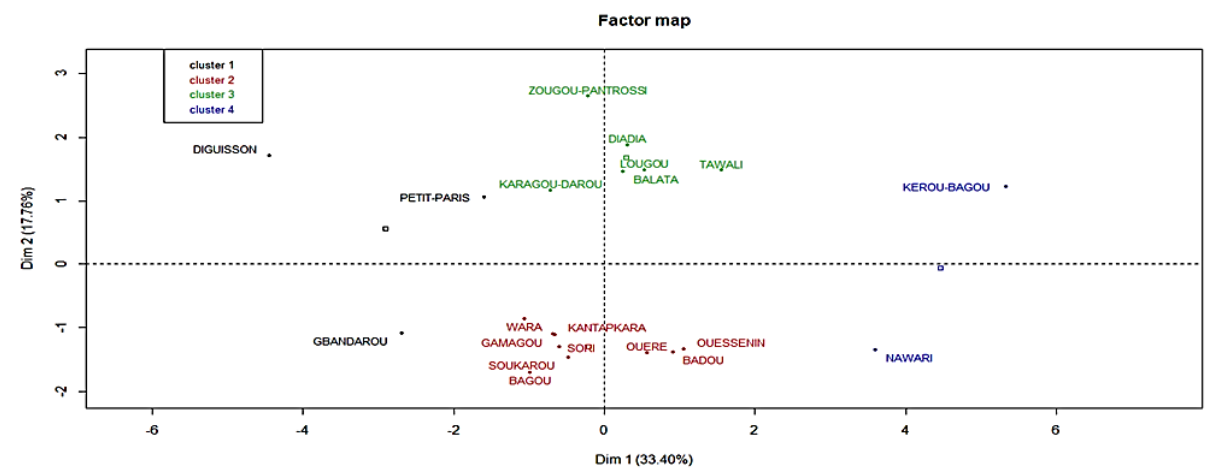

Fig. 2 First factorial plan for the distribution of dams according to technical characteristics

Table 1. Average values, minimum and maximum standard deviation of technical characteristics

\begin{tabular}{|c|c|c|c|c|}
\hline Variable & Average & Standard deviation & Minimum & Maximum \\
\hline Age & 18 & 4 & 12 & 24 \\
\hline Dike length & 182,3 & 78,2 & 0,0 & 300,0 \\
\hline Weir length & 24,6 & 10,2 & 0,0 & 35,0 \\
\hline Bowl depth & 4,4 & 1,5 & 1,5 & 7,0 \\
\hline Maximum dam capacity & 55220 & 18961 & 20000 & 100000 \\
\hline $\begin{array}{c}\text { Distance from the closest fields } \\
\text { to the dam }\end{array}$ & 60,1 & 88,7 & 1 & 300 \\
\hline $\begin{array}{c}\text { Distance from the closest } \\
\text { village to the dam }\end{array}$ & 960 & 839 & 0 & 3500 \\
\hline
\end{tabular}

Table 2. Distribution of the four (04) groups of dams according to the type of dam and the place of installation

\begin{tabular}{|c|c|c|c|c|c|c|c|c|}
\hline Paramètres & Groupe & Age & $\begin{array}{l}\text { Length } \\
\text { of the } \\
\text { dike }\end{array}$ & $\begin{array}{l}\text { Weir } \\
\text { lenght }\end{array}$ & $\begin{array}{l}\text { Depth } \\
\text { of the } \\
\text { basin }\end{array}$ & Cap_max_barg & DCPPB & DVPPB \\
\hline \multirow{4}{*}{ Moyenne } & 1 & 23 & 40,0 & 5,0 & 3,8 & 38333 & 11,3 & 600 \\
\hline & 2 & 19 & 203,3 & 27,2 & 3,9 & 52556 & 58,9 & 950 \\
\hline & 3 & 17 & 191,2 & 27,8 & 4,5 & 54400 & 105,2 & 1275 \\
\hline & 4 & 13 & 275,0 & 32,5 & 7,0 & 95000 & 4,0 & 600 \\
\hline \multirow{4}{*}{ ЕсТур } & 1 & 1 & 69,3 & 8,7 & 2,0 & 16073 & 12,1 & 794 \\
\hline & 2 & 4 & 43,1 & 5,1 & 1,2 & 10760 & 93,0 & 552 \\
\hline & 3 & 3 & 40,0 & 6,4 & 0,8 & 15811 & 104,4 & 1273 \\
\hline & 4 & 1 & 35,4 & 3,5 & 0,0 & 7071 & 1,4 & 566 \\
\hline \multirow{4}{*}{ Minimum } & 1 & 22 & 0,0 & 0,0 & 1,5 & 20000 & 2,0 & 0 \\
\hline & 2 & 14 & 150,0 & 20,0 & 1,5 & 40000 & 5,0 & 0 \\
\hline & 3 & 13 & 125,0 & 20,0 & 3,0 & 35000 & 1,0 & 50 \\
\hline & 4 & 12 & 250,0 & 30,0 & 7,0 & 90000 & 3,0 & 200 \\
\hline \multirow{4}{*}{ Maximum } & 1 & 24 & 120,0 & 15,0 & 5,0 & 50000 & 25,0 & 1500 \\
\hline & 2 & 23 & 255,0 & 35,0 & 6,0 & 70000 & 300,0 & 2000 \\
\hline & 3 & 21 & 240,0 & 35,0 & 5,0 & 80000 & 300,0 & 3500 \\
\hline & 4 & 14 & 300,0 & 35,0 & 7,0 & 100000 & 5,0 & 1000 \\
\hline
\end{tabular}

Long_dig = Length of the dike, Long_devr = Weir length, Prof_cuv $=$ Depth of the basin, Cap_max_bar $=$ Maximum dam capacity, DCPP $=$ Distance from the Closest Field, DVPP $=$ Distance from the Closest Village 


\section{sciendo}

120 Ovidius University Annals Series: Civil Engineering, Year 22, 2020

Table 3: Characteristic parameters of the four (04) groups of dams (quantitative variables) identified

\begin{tabular}{|c|c|c|c|c|}
\hline Droups & $\begin{array}{c}\text { Pastoral } \\
(\%)\end{array}$ & $\begin{array}{c}\text { Agricol } \\
(\%)\end{array}$ & $\begin{array}{c}\text { Agropastoral } \\
(\%)\end{array}$ & $\begin{array}{c}\text { Inondable } \\
(\%)\end{array}$ \\
\hline 1 & 67 & 0 & 33 & 33 \\
\hline 2 & 0 & 0 & 100 & 56 \\
\hline 3 & 100 & 0 & 0 & 50 \\
\hline 4 & 50 & 50 & 100 & 50 \\
\hline
\end{tabular}

\subsection{Categorization of dams according to technical characteristics}

The first factorial plan resulting from the numerical classification and the principal component analysis shows the distribution of the dams according to the technical characteristics and some qualitative variables (Figure 1). This factorial plan explains $51.16 \%$ (33.40\% for axis 1 and $17.76 \%$ for axis 2 ) of the information concerning the distribution of dams according to the characteristics. Four major dam groups have been identified. The characteristics of each group are presented in Tables 2 and 3.

Figure 3 shows the distribution of dams according to their mode of operation. It emerges from the analysis of this figure that there are management committees around all the dams in the commune of Gogounou, but as for functionality, nearly $75 \%$ are nonfunctional, maintenance is done only for $15 \%$ of dams, and on $85 \%$ there is no monitoring or maintenance. Compared to the existence of a goalkeeper, it's only on $35 \%$ of the playoff. Figure 3 the distribution of dams according to their operating mode.

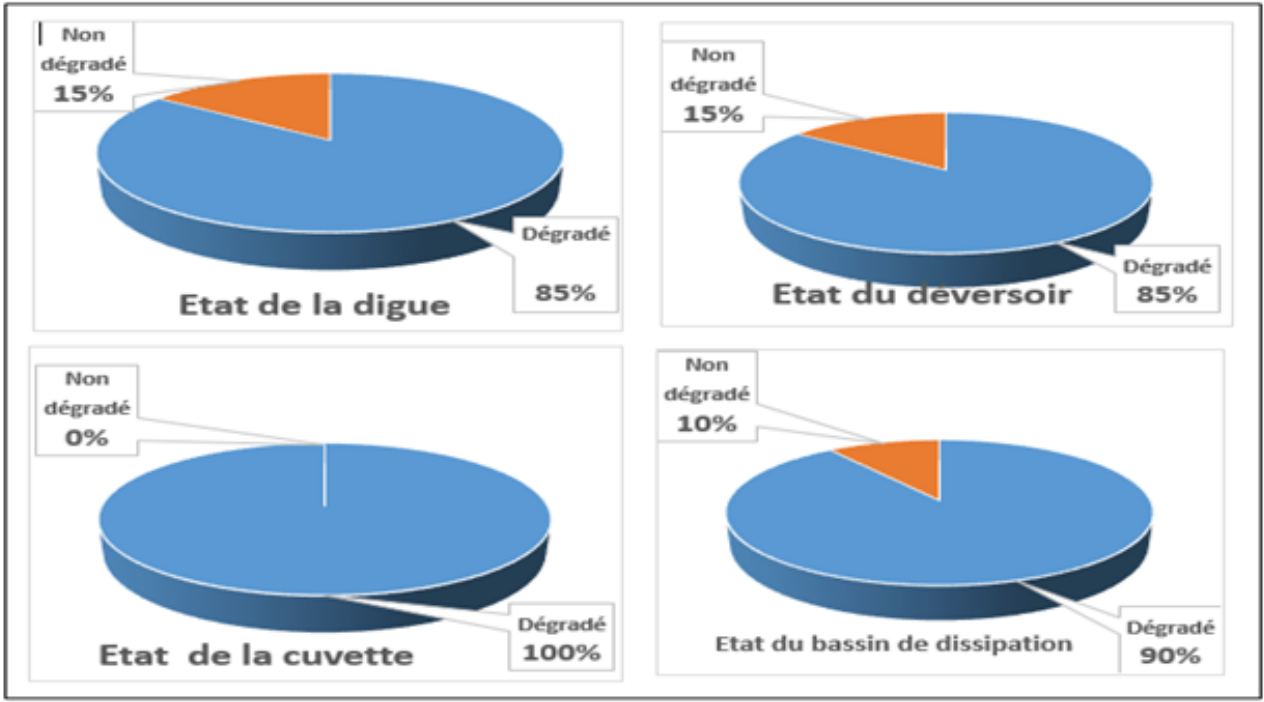

Fig. 2 Damage condition of dams 


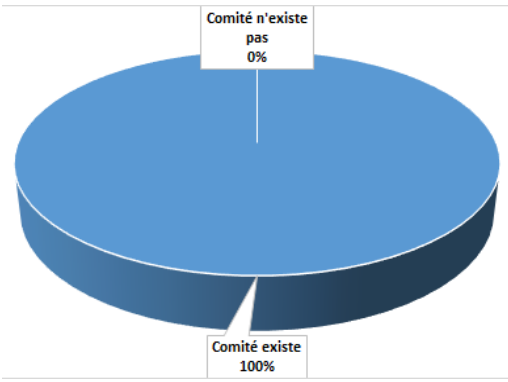

Existence de com/gestion

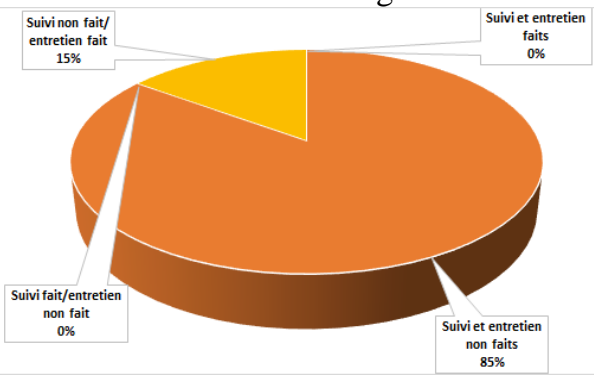

Suivi-entretien du barrage

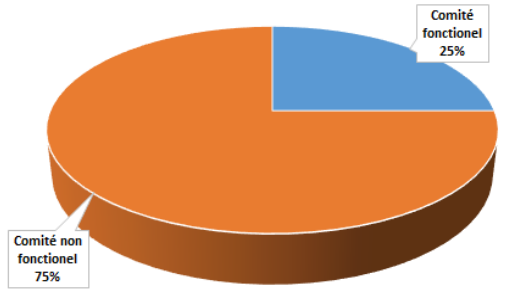

Fonctionnalité du com/gestion

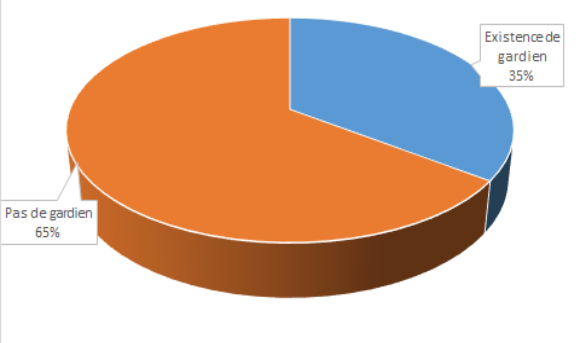

Existence de Gardien

Fig. 3 The distribution of dams according to their operating mode

\subsection{Activities around dams}

\subsubsection{Agriculture}

Table 4 shows the distribution of dams according to the activities practiced around them. Analysis of the table shows that the crops grown around the dams are corn $(90 \%)$, cotton $(70 \%)$ tubers $(15 \%)$, legumes $(20 \%)$, vegetable crops $(45 \%)$ and other crops $(0.005)$. In general in $95 \%$ of dams, producers use small tools for agriculture, in $25 \%$ they use motor pumps, in $45 \%$ they use organic fertilizers, in $90 \%$ they use mineral fertilizers. Insecticides and herbicides are also used in $90 \%$ of dams. Images 5, 6, 7 and 8 show some characteristic elements of agricultural practices around dams.

Table 4: Distribution of dams according to agricultural practices

\begin{tabular}{|c|c|c|c|c|c|c|c|c|}
\hline & & & & & & & & \\
\hline Speculation & $\%$ dams & $\begin{array}{l}\text { Cultivated area } \\
\text { around the dams } \\
\text { (ha) }\end{array}$ & $\begin{array}{l}\frac{n}{0} \\
\stackrel{0}{0} \\
\bar{\Xi} \\
\text { ๘ }\end{array}$ & 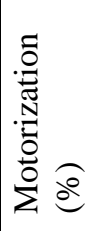 & 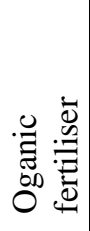 & 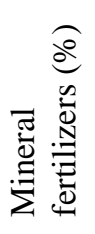 & 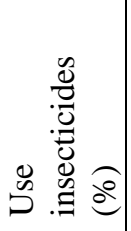 & 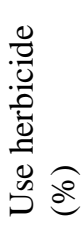 \\
\hline Corn & 90 & 6,55 & & & & & & \\
\hline Cotton & 70 & 4,69 & & & & & & \\
\hline Tubers & 15 & 0,05 & & 25 & 45 & 9 & 00 & \\
\hline Legumes & 20 & 0,15 & 95 & 25 & 45 & 90 & 90 & 90 \\
\hline Vegetable crops & 45 & 0,34 & & & & & & \\
\hline Others & 5 & 0,005 & & & & & & \\
\hline
\end{tabular}




\section{sciendo}

122 Ovidius University Annals Series: Civil Engineering, Year 22, 2020

\subsubsection{Breeding the breeders are mostly transhumant and sedentary}

Figure 4 shows the distribution of dams according to the type of animal that drinks. Dams are used for watering cattle and sheep in $100 \%$ of the cases and goats in $65 \%$ of the cases. The mean, standard deviation, minimum and maximum values of the numbers of different types of animals, presented in table 12 show that on average at the level of a dam $(4868 \pm 4045)$ cattle heads drink with sometimes in places 19,436 cattle and 1,448 cattle for the least populated dams. For sheep on average $(3,372 \pm 10,129)$ sheep are present in dams with sometimes 46,344 sheep in places and 250 sheep for the least populated dams. For goats on average $(82 \pm 132)$ goats are present in the dams with sometimes 542 goats.

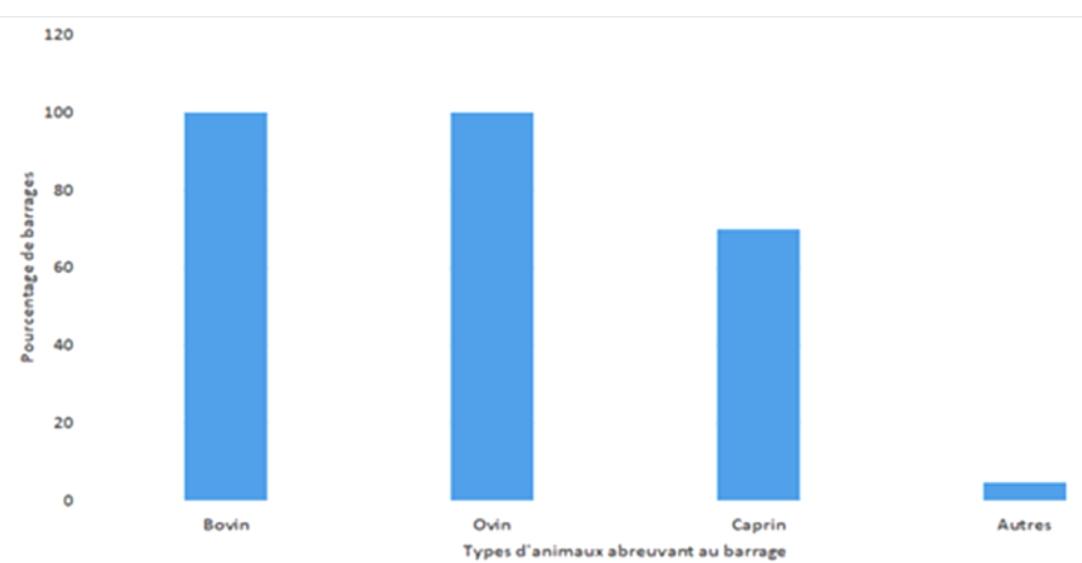

Fig. 4 Distribution of dams according to the type of animal that drinks

Fishing and conflicts on $90 \%$ of the dams, the fishermen who carry out their activity are natives. Non-natives work on $25 \%$ of the dams. The type of fishing practiced is traditional (on $95 \%$ of dams) and modern (on $5 \%$ of dams). The fishing season varies from February to March in general and their frequency is 1 to 3 times a year. The average quantity of fish is $432.05 \mathrm{~kg}$ per dam with a standard deviation value of 387,432 . The analysis in Figure 5 shows that there are different types of conflicts. On all the dams, there are land conflicts $(100 \%)$, on around $78 \%$ of the dams there are conflicts between actors and on $40 \%$ there are conflicts within the management committee.

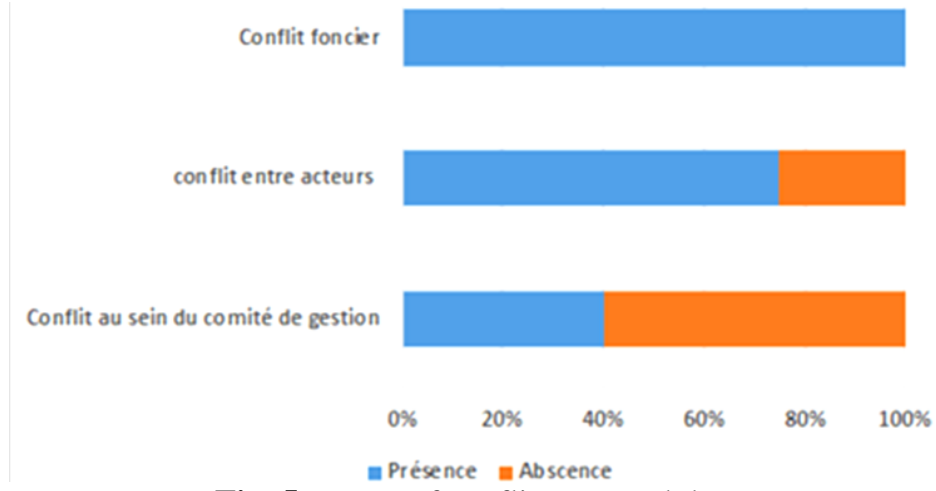

Fig. 5 Nature of conflicts around dams 


\section{sciendo}

\subsection{Conflict management}

In the context of conflict management, several types of regulations are used: For conflicts related to the Management Committee, at the level of $57 \%$ of the dams, these conflicts are settled amicably, but sometimes the gendarmerie is called upon $(9 \%$ of the dams), or traditional and religious leaders (5\% of the dams), or the town hall (5\% of dams) or the village chief ( $24 \%$ of dams). For conflicts related to agriculture, for $41 \%$ of cases, these conflicts are settled amicably but sometimes the recourse of the gendarmerie is used $(6 \%)$, or traditional and religious leaders $(3 \%)$, or town hall $(15 \%)$ or the village chief (35\%). For conflicts related to animal husbandry, in $(37 \%)$ of cases, these conflicts are settled amicably but sometimes breeders have recourse to the gendarmerie (9\%), traditional and religious leader $(6 \%)$, the town hall $(14 \%)$ or the village chief $(34 \%)$. For conflicts related to fishing, in $(55 \%)$ of cases, these conflicts are settled amicably but sometimes the police is solicited $(40 \%)$, or the town hall $(18 \%)$ or even the village chief $(23 \%)$ Management Agricultural Committee.
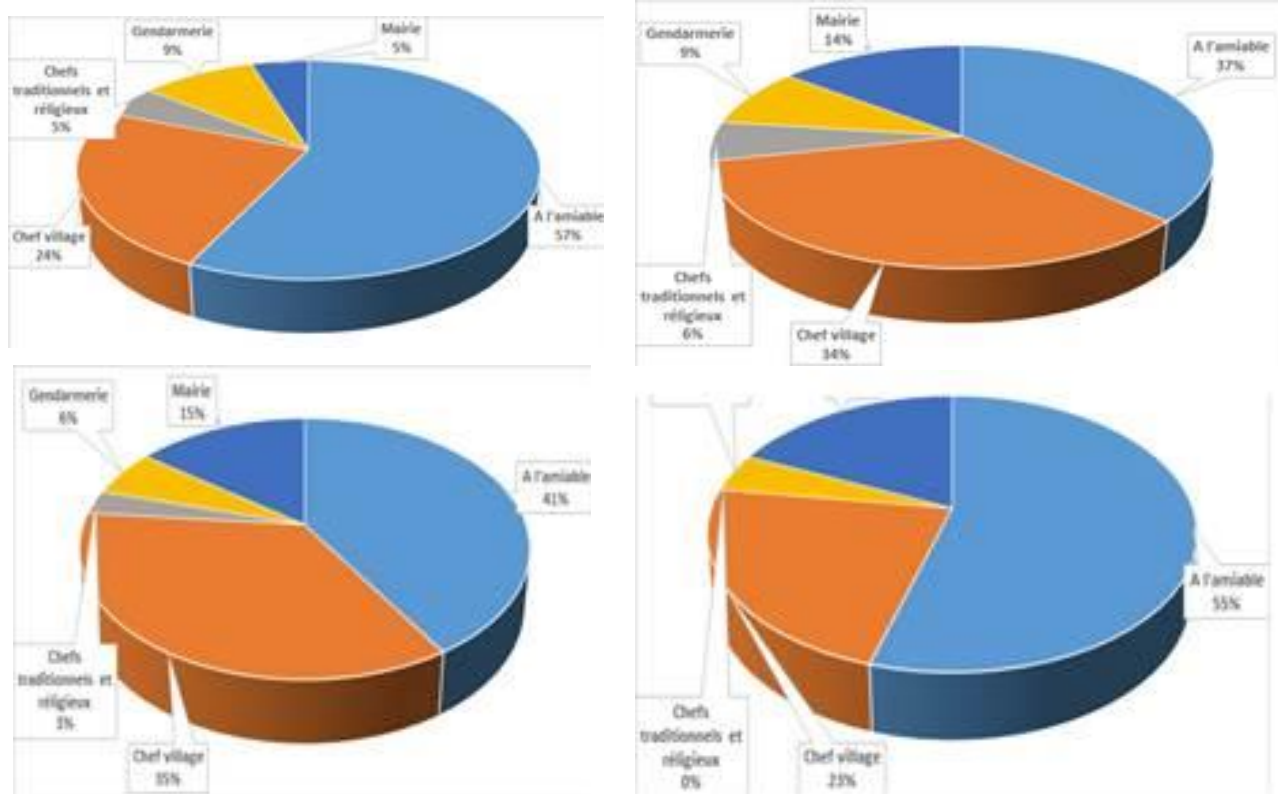

Fig. 6 Conflict management

\subsection{Dams capacity and level of taking away}

The diagram 7 shows the storage capacity of dams taken for the different use and the total quantity of rain during the year $(11000 \mathrm{~mm})$ in the district. As a result for the diagram le level of taken away varies from one dam to another,divide to the quantity of water retention per dam.However in the majorityof dams, both quantity (taking away an rain) tend to beapproached.The results also show that the das of Diguisson, Karakou-Darou, Lougou, Ouèrè, and Petit-paris have storage capacity which tend to the taking away level.For rainfall quantity (Figure 7, Rainfall day till December $31^{\text {th }}$ ). The higher rate of rain has been registered in the area of Kantapkara, Sori, Soukarou, Tawali, Diguisson et KerouBagou. 


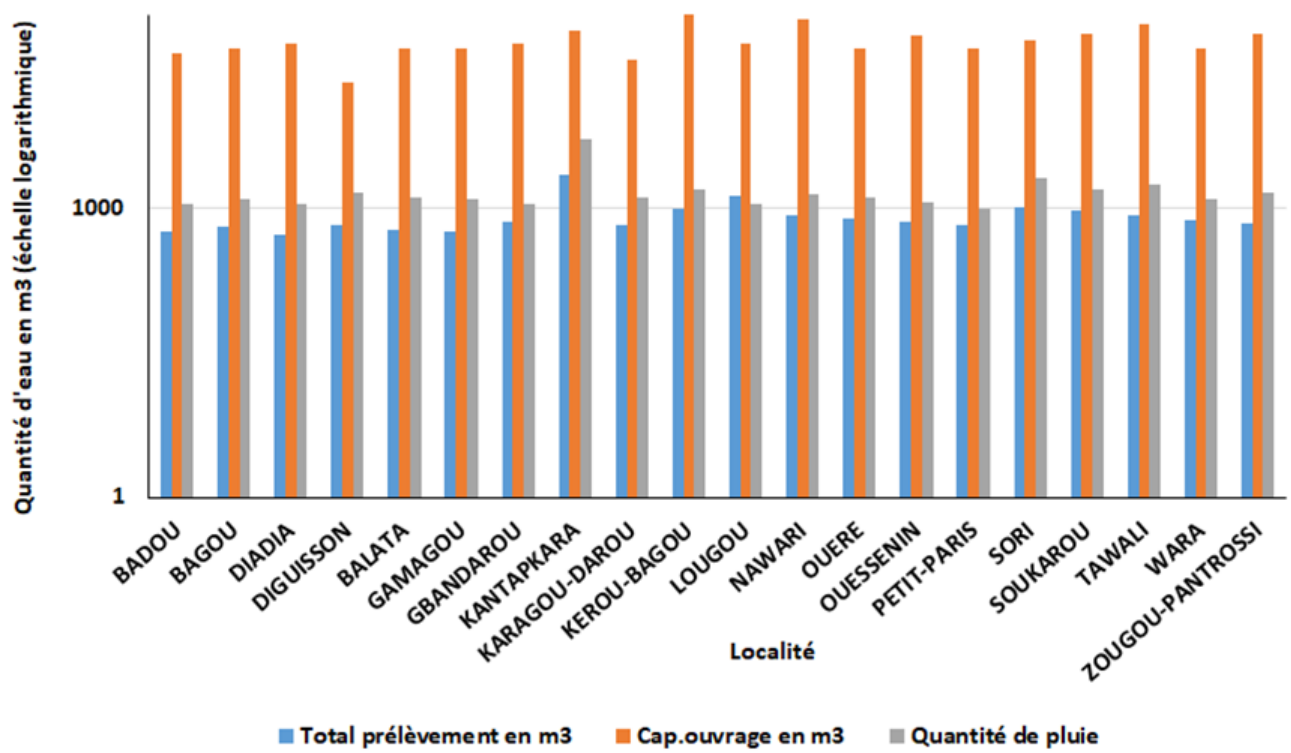

Fig. 7 Storage capacity, amount of water withdrawn and total amount of rain during the year per dam (on a logarithmic scale)

\section{DISCUSSIONS}

The advanced state of Figure degradation of the dams is due to their technical characteristics, to the congestion of the basin due to the effects of erosion induced by advanced desertification in the study area. The results obtained also corroborate those of [5]. The results of our research have shown that dam degradation is a function of age and more or less defective technical characteristics linked to the design and the economic choice of designers [9]. Our research also shows that all dams have more or less functional management committees. This increases the risk of conflicts between the different users, the lack of monitoring and control around the reservoirs, especially for cases where the dams are unattended. Authors like [14] [8] [6] [10] [12] [1] all demonstrated the importance of water point management committees with a relatively complex common organization of the various users (farmers, breeders, fishermen). Agropastoral activities are developing around dams. This situation was pointed out by the author [8] who shows that the dam allows the appearance of new activities, market gardening and fishing. But the uncontrolled development of activities is depleting water resources, the disappearance of fishing and the lack of water for market gardening. In addition, our research has shown that some dams have a low storage capacity despite the large amount of rainwater recorded in its areas. This would be due to a poor technical design of the structure or to the high anthropic pressure which can cause the degradation of the structures. These results corroborate those of the author [4] which show that the design of a dam must take. 


\section{Conclusions}

Despite the advent of the National Water Policy and the law on water management in the Republic of Benin, it should be noted that water management in the field of agriculture, livestock and fishing is not yet well controlled, given the current requirements of Integrated Water Resources Management. Our study which focused on "Agropastoral dams in the town of Gogounou: Categorization and Management" showed that dams are sources of water for the water needs of the population for agriculture, livestock and fishing. In addition, these results have shown that the state of degradation of dams is a function of their age and more or less defective technical characteristics linked to the design and the economic choice of the designers. Therefore, it is important to make an exhaustive statement of these works for their rehabilitation and good management according to the four groups of dams identified. Furthermore, this study highlights the lack of control over conflicts related to land, which are very often recurrent due to anthropogenic pressure, free access to sites and the large number of livestock in the study environment. These conflicts related to the operation of dams exist and are generally settled amicably between users, even if some cases are managed at the level of the municipal administration, the gendarmerie and with traditional and religious leaders. In perspective, it would be desirable to determine scenarios in terms of adaptation to climate change to assess the behavior of dams, in order to develop models to study the reliability, resilience and vulnerability of resisting the future climate.account the technical characteristics of the structure and the hydrological profile of the zone under modified climate

\section{REFERENCES}

[1] Baudoux, L., Kamil, H., Moulin, C.-H., (2005) Développement de l'agropastoralisme chez une fraction nomade fixée sur les bords du fleuve Niger au Mali= Productividad numérica y ponderal de las ovejas originadas de cruces entre la D'man y la raza local Cola fina del oeste = Numerical and wieght productivities of crossbred D'man by local Queue fine de l'Ouest ewes. Rev. Délevage Médecine Vét. Pays Trop. 58

[2] Daniel, W., Kevin, M., (2015) Les exigences en eau du bétail [WWW Document]. URL http://www.omafra.gov.on.ca/french/engineer/facts/07-024.htm (accessed 4.25.18).

[3] Ganta Bonkonon (2019) Café de la Science : L'agriculture béninoise face au défi du changement/variabilité climatique / L'actualité / Toute l'actualité / Bénin / IRD - Sites de représentation / IRD - Bénin [WWW Document]. URL http://benin.ird.fr/toute-lactualite/l-actualite/cafe-de-la-science-l-agriculture-beninoise-face-au-defi-duchangement-variabilite-climatique (accessed 10.30.19)

[4] Hypatie, N., (2007) Introduction du changement climatique dans un modelé technico-économique de gestion de l'eau (Mémoire de master en transport et développement durable). Ecole des ponts et chaussées, école polytechnique, école des mines

[5] Kassoul, M., Abdelgader, A., Belorgey, M., (1997) Caractérisation de la sédimentation des barrages en Algérie. Rev. Sci. EauJournal Water Sci. 10, 339-358

[6] Katè, S., Amagnidé, A., Hounmenou, C.G., Hounkpatin, E.L., Sinsin, B., (2015) Changements climatiques et gestion des ressources pastorales en zone agropastorale au Nord-Bénin: cas de la commune de Banikoara. Afr. Sci. 11, 201-215 


\section{sciendo}

126 Ovidius University Annals Series: Civil Engineering, Year 22, 2020

[7] Krüger, B., (2017) Cactus 2000: Précipitations [WWW Document]. URL https://www.cactus2000.de/fr/unit/massrai.shtml (accessed 5.2.18)

[8] Labbé, O., (2007) Analyse institutionnelle de la gestion et des usages de l'eau en Afrique de l'ouest: Bassins du Niger et de la Volta

[9] Lautrin, D., (2003) Vieillissement et réhabilitation des petits barrages en terre, Editions Quae

[10] Moore, K.M., Kaboré, D., Gnoumou, B., Bertelsen, M., (1999) Conflit et gestion des ressources naturelles dans les systems agraires et pastoraux des regions arides et semi-arides de l'afrique de l'ouest

[11] PDC 3 Gogounou [WWW Document], (2017) URL http://www.ancbbenin.org/pdc-sdac.../PDC/Alibori/Gogounou (accessed 5.8.18)

[12] Richard-Ferroudji, A., (2008) L'appropriation des dispositifs de gestion locale et participative de l'eau-Composer avec une pluralité de valeurs, d'objectifs et d'attachements (PhD Thesis). Ecole des Hautes Etudes en Sciences Sociales (EHESS)

[13] Vissin, E., (2007) Impact de la variabilité climatique et de la dynamique des états de surface sur les écoulements du bassin béninois du fleuve Niger (PhD Thesis). Universite de Bourgogne

[14] Vissin, E.W., (2017) Conflits d'usage dans le bassin béninois du fleuve Niger en Afrique de l'ouest dans le contexte de la Gestion Intégrée des Ressources en Eau

Note:

Roger Masso Sourogou - PhD student in Natural Resources Management at the University of Parakou in Benin, CDE Rd, Parakou, Benin, tel.: (229)97859741 (e-mail: cisourogoumassoroger@yahoo.fr).

Fabien. C. Hountondji - National Higher School of Marine Sciences and Coastal Management (ENSSMAL). CDE Rd, Parakou, Benin, (e-mail: fabienho@yahoo.com) 